\title{
Small size today, aquarium dumping tomorrow: sales of juvenile non-native large fish as an important threat in Brazil
}

\author{
André L. B. Magalhães ${ }^{1}$, Mário L. Orsi², Fernando M. Pelicice ${ }^{3}$,Valter M. \\ Azevedo-Santos ${ }^{4}$, Jean R. S. Vitule ${ }^{5}$, Dilermando P. Lima-Junior ${ }^{6}$ and Marcelo F. G. Brito ${ }^{7}$
}

Informal sales of large-bodied non-native aquarium fishes (known as "tankbusters") is increasing among Brazilian hobbyists. In this study, we surveyed this non-regulated trade on Facebook ${ }^{\circledR}$ from May 2012 to September 2016, systematically collecting information about the fishes available for trading: species, family, common/scientific names, native range, juvenile length, behavior, number of specimens available in five geographical regions from Brazil. We also assessed the invasion risk of the most frequently sold species using the Fish Invasiveness Screening Test (FIST). We found 93 taxa belonging to 35 families. Cichlidae was the dominant family, and most species were native to South America. All species are sold at very small sizes $(<$ $10.0 \mathrm{~cm}$ ), and most display aggressive behavior. The hybrid Amphilophus trimaculatus $\times$ Amphilophus citrinellus, Astronotus ocellatus, Uaru amphiacanthoides, Osteoglossum bicirrhosum, Cichla piquiti, Pangasianodon hypophthalmus, Datnioides microlepis and Cichla kelberi were the main species available. The southeast region showed the greatest trading activity. Based on biological traits, the FIST indicated that Arapaima gigas, C. kelberi and C. temensis are high-risk species in terms of biological invasions via aquarium dumping. We suggest management strategies such as trade regulations, monitoring, euthanasia and educational programs to prevent further introductions via aquarium dumping.

Keywords: Aquarium releases, Aquarium trade, Biological invasions, Invasiveness, Propagule pressure.

A venda de juvenis de peixes não-nativos de grandes dimensões, chamados de "peixes jumbo", está aumentando entre aquaristas no Brasil. Neste trabalho, pesquisou-se este comércio informal pelo Facebook ${ }^{\circledR}$ de maio/2012 a setembro/2016, coletando-se informações sobre espécies, família, nomes vulgares/científicos, origem, tamanho juvenil, comportamento e número/frequência de exemplares disponíveis nas cinco regiões geográficas do Brasil. Também avaliou-se o risco de invasão das espécies mais vendidas usando o protocolo Fish Invasiveness Screening Test (FIST). Foram encontradas 93 espécies pertencentes a 35 famílias. Cichlidae foi a família dominante, e a maioria das espécies é nativa da América do Sul. Todas as espécies foram vendidas como juvenis $(<10.0 \mathrm{~cm})$, e a maioria exibe comportamento agressivo. O híbrido Amphilophus trimaculatus $\times$ Amphilophus citrinellus, Astronotus ocellatus, Uaru amphiacanthoides, Osteoglossum bicirrhosum, Cichla piquiti, Pangasianodon hypophthalmus, Datnioides microlepis e Cichla kelberi foram as espécies mais comercializadas. A região sudeste apresentou a maior porcentagem de vendas, e o FIST mostrou que Arapaima gigas, $C$. kelberi e C. temensis foram consideradas de alto risco para desencadear invasões biológicas mediadas por descarte de aquários. Recomendações como a regulação do comércio, monitoramento, sacrifício das espécies e campanhas educacionais para os aquaristas são sugeridas para evitar futuras introduções de peixes via descarte de aquários.

Palavras-chave: Comércio ornamental, Invasividade, Invasões biológicas, Pressão de propágulos, Solturas de aquaristas.

\footnotetext{
${ }^{1}$ Programa de Pós-Graduação em Tecnologias para o Desenvolvimento Sustentável, Universidade Federal de São João Del Rei, Rod. MG 443, KM 7 Fazenda do Cadete, 36420-000 Ouro Branco, MG, Brazil. (ALBM) andrebiomagalhaes@gmail.com (corresponding author) ${ }^{2}$ Departamento de Biologia Animal e Vegetal, Universidade Estadual de Londrina, Rod. Celso Garcia Cid s/n, Perobal, 86051-990 Londrina, PR, Brazil.orsimario68@gmail.com

${ }^{3}$ Núcleo de Estudos Ambientais, Universidade Federal do Tocantins, Rua 03 Quadra 17, Jardim dos Ipês, $77500-000$ Porto Nacional, TO, Brazil. fmpelicice@gmail.com

${ }^{4}$ Laboratório de Ictiologia, Universidade Estadual Paulista “Júlio de Mesquita Filho", 18618-970 Botucatu, SP, Brazil. valter. ecologia@gmail.com

${ }^{5}$ Laboratório de Ecologia e Conservação, Universidade Federal do Paraná, Jardim das Américas, 81531-970 Curitiba, PR, Brazil. biovitule@gmail.com

${ }^{6}$ Laboratório de Ecologia e Conservação de Ecossistemas Aquáticos, Universidade Federal do Mato Grosso, Rodovia MT 100, Km 3,5 Setor Universitário, 78698-000 Pontal do Araguaia, MT, Brazil. dilermando.lima@gmail.com

${ }^{7}$ Programa de Pós-Graduação em Ecologia e Conservação, Universidade Federal de Sergipe, Av. Marechal Rondon S/N, Jardim Rosa Elze, 49100-000 São Cristóvão, SE, Brazil. marcelictio@gmail.com
} 


\section{Introduction}

Fishkeeping is a worldwide hobby appretiated by people of all ages (CBD, 2010). It has been shown that aquarium keeping improves human well-being in many aspects, e.g. the development of responsibility in children (Edwards, Beck, 2002), reduction of stress levels in adults, and improved physical and psychological well-being in the elderly (Reaser, Meyers, 2007). The United States is the leading country in the number of hobbyists, with about 20 million enthusiasts (Chapman, 2000). Estimates indicate that american homes have 151.6 million ornamental fishes (APPMA, 2008), followed by the United Kingdom, with 140 million fishes (Marine \& Coastal Committee, 2005). In Brazil, it is a growing hobby with 26 million fishes belonging to more than 300 species, being the second most frequent pet (AquaA3, 2015).

Fishkeeping is increasing in popularity, but hobbyists are poorly informed or reckless about environmentally friendly practices (Duggan et al., 2006; Gertzen et al., 2008; Holmberg et al., 2015; Maceda-Veiga et al., 2016). For example, excessive growth and unexpected aggressive behavior of fishes may lead to environmental problems, i.e, aquarium dumping (Duggan et al., 2006; Gertzen et al., 2008). Under these circumstances, many hobbyists are poorly informed about adequate practices (i.e, correct disposal of pets or even sacrifice), and discard unwanted pets into nearby waterways (Duggan et al., 2006; Gertzen et al., 2008; Magalhães, Jacobi, 2013a; Azevedo-Santos et al., 2015; Maceda-Veiga et al., 2016). Pet abandonment has become one of the most challenging issues in biosecurity concerning species invasions (CBD, 2010). For instance, in Australia, Taiwan, Singapore and Japan, aquarium dumping is the main cause of non-native fish species introduction (Bomford, Glover, 2004; Liang et al., 2006; Ng, Tan, 2010; Ishikawa, Tachihara, 2014). In Brazil, where native fish diversity is high (Frehse et al., 2016), official reports of aquarium dumping are rare, but evidence indicates that this activity is frequent and increasing in several regions (Gomes et al., 2011; Magalhães, Jacobi, 2013a; Garcia et al., 2014; AzevedoSantos et al., 2015; França et al., 2017). There are records regarding small characids, osphronemids and poeciliids (Magalhães, Jacobi, 2013a; Azevedo-Santos et al., 2015), but the market of large-bodied non-native aquarium fishes may represent an important source of fish propagules. Sales of large ornamental species, known as "tankbusters" among hobbyists, has grown rapidly in the last decade (Magalhães, Jacobi, 2010; Gomes et al., 2011; Magalhães, Jacobi, 2013a; Garcia et al., 2014; França et al., 2017). Different large species have been translocated among watersheds, including fishes from the Amazon basin (e.g. freshwater stingrays Potamotrygon spp., sailfin catfishes Pterygoplichthys spp.) and/or imported from other countries (e.g. alligator gar Atractosteus spatula (Lacepède, 1803), striped catfish
Pangasianodon hypophthalmus (Sauvage, 1878)) (Garcia et al., 2014; Azevedo-Santos et al., 2015). As ornamental fishkeeping practices spread in Brazil (Gomes et al., 2011; Magalhães, Jacobi, 2013a; Assis et al., 2014; Garcia et al., 2014; Magalhães, 2015), an informal trade system has developed among hobbyists, which is currently nonregulated, non-monitored and apparently not recognized by environmental agencies (Magalhães, 2015).

In order to understand this non-regulated market and the environmental risks associated, this study evaluated the sales of juvenile non-native large fish (JNLF, hereafter) among Brazilian hobbyists, via face-to-face personal contacts. So far, the importance of this new vector had not been evaluated consistently in Brazil, an here we present an overview of species available for trading, quantity, sizes, origin and ecological information related to their invasion risk. Based on this data, we discuss management strategies to prevent further invasions into Brazilian water bodies via aquarium dumping.

\section{Material and Methods}

Data sampling. We surveyed the informal ornamental trade in the Facebook ${ }^{\circledR}$ (www.facebook.com) from May-2012 to September-2016. Ten hobbyist groups (i.e, exclusive sale groups of ornamental large fishes) were chosen randomly using standardized keywords (e.g. jumbo fishes, jumbo fish sales, jumbo cichlids, Brazil jumbo fishes, jumbo fishkeepers, keeping large fish, Central American cichlids) and monitored four times every month (once a week in the same day). To conduct the monitoring, one researcher (A.L.B. Magalhães) became a member of the group but did not contact any hobbyist during the period, so the trading process was not disturbed. The trade operates as follows: the hobbyist announces the species showing a picture, common or scientific name, juvenile length, price (Real currency) and location. When the purchase is agreed, hobbyists schedule to meet and complete the deal in privacy.

To determine the availability of JNLF for sale, we surveyed only fish species with maximum adult lengths above $20 \mathrm{~cm}$. When a hobbyist announced the same species in more than one group, replicates were discarded. From the ten Facebook ${ }^{\circledR}$ aquarium groups, we recorded information about the fishes on sale: length, number of specimens and geographical availability, considering 11 large urban centers of the north (Belém), northeast (São Luís, Fortaleza, João Pessoa, Recife, Salvador), mid-west (Brasília), southeast (Belo Horizonte, Rio de Janeiro, São Paulo), and south (Curitiba) regions of Brazil (Fig. 1). In addition, the family, common/scientific names, native range, maximum adult length and aggressiveness of these species were consulted in Axelrod (1992), Sandford, Crow (1996), Axelrod et al. (2005), Liew et al. (2012), Motionaquaticsuk (2016), Froese, Pauly (2016), Nelson et al. (2016), and Eschmeyer et al. (2017). 


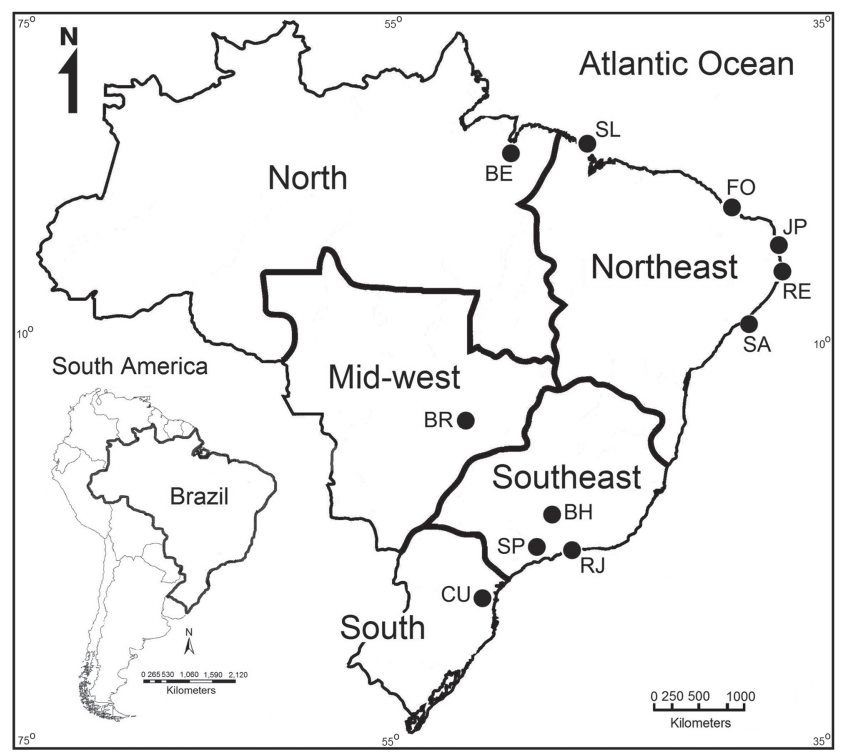

Fig. 1. Five main geopolitical regions of Brazil and the 11 cities where we monitored the unregulated market of juveniles of non-native large fishes. Brazilian cities/population/states surveyed: BE - Belém/1,446,042 inhabitants/Pará, SL - São Luís/1,082,935 inhabitants/Maranhão,FO-Fortaleza/2,609,716 inhabitants/Ceará, JP - João Pessoa/801,718 inhabitants/ Paraíba, RE - Recife/1,625,583 inhabitants/Pernambuco, SA - Salvador/2,938,092 inhabitants/Bahia, BR - Brasília (capital city of Brazil)/2,977,216 inhabitants/Distrito Federal, BH - Belo Horizonte/2,513,451 inhabitants/Minas Gerais, RJ - Rio de Janeiro/6,498,837 inhabitants/Rio de Janeiro, SP - São Paulo/12,038,175 inhabitants/São Paulo, CU Curitiba/1,893,997 inhabitants/Paraná (IBGE, 2016).

Data analysis. We calculated the total number of species available in the market, and according to families and native origin. We also calculated specimens availability, for each species and geographical region. The Kruskal-Wallis nonparametric analysis of variance (Sokal, Rohlf, 1995) was used to test differences in mean length between juvenile fishes on sale and their maximum lengths when adults. This test considered only the 15 most frequently available (announced for sale) species, which were pooled across species to test overall differences in length.

We also assessed the invasion risk of these top 15 species using a simple risk assessment protocol named Fish Invasiveness Screening Test (FIST) (Singh, Lakra, 2011). This index includes the screening of potential biological traits related to invasion risk, such as maximum adult length, aggressiveness, tolerance to salinity, history of establishment, breeding in the wild and competition with local species. For each species, traits were classified as + (low), ++ (moderate) and +++ (high), according to the literature (Nico et al., 2007; Ng, Tan, 2010; Herder et al., 2012; Jaafar et al., 2012; Liew et al., 2012; Carvalho et al., 2014; Pelicice et al., 2015; Motionaquaticsuk, 2016; Froese, Pauly, 2016). Traits were categorized in the following way: 1) Maximum adult length $(+=20.0$ to $40.0 \mathrm{~cm},++=40.1$ to 60.0 $\mathrm{cm},+++=$ above $60.1 \mathrm{~cm})$; 2) Aggressiveness $(+=$ harmless,
$++=$ peaceful, $+++=$ aggressive); 3 ) Tolerance to salinity ( + $=$ freshwater, $++=$ freshwater/brackish, $+++=$ saltwater $) ; 4)$ History of establishment ( $+=0$ to 7 countries, $++=8$ to 15 countries, $+++=$ more than 16 countries); 5 ) Breeding in the wild $(+=$ absent,$++=$ low to moderate, $+++=$ high); 6 ) Competition with local species $(+=$ absent, $++=$ low to moderate, $+++=$ high). We then calculated the frequency (FD\%) of the +++ class among the six screened traits, and used this value to determine the risk level for each species. To determine invasion risk associated with aquarium dumping, we used criteria similar to Singh, Lakra (2011), where species with FD $\%$ above $50 \%$ were classified as high-risk, species with FD\% between 30 and 50\% were classified as medium-risk, and species with $\mathrm{FD} \%$ below $30 \%$ were classified as low-risk.

\section{Results}

We encountered sales of 93 taxa of JNLF, being 89 valid species and four hybrids (Appendix S1 - Available only as online supplementary file accessed with the online version of the article at http://www.scielo.br/ni). These taxa belonged to 35 families, native to six continents and one region. Among the families, Cichlidae was the dominant (34 species), followed by Polypteridae, Loricariidae and Cyprinidae (four species each). Potamotrygonidae, Osteoglossidae, Notopteridae and Serrasalmidae were represented by three species, while the remaining were represented by two or one species (Fig. 2). According to their native origin, 43 species $(46.24 \%)$ were native to South America, especially the Amazon region (36.56\%), followed by Africa and Asia (17.20\% each), Central America (11.83\%), North America (4.30\%), Oceania (2.15\%) and Caribbean (1.08\%) (Fig. 3).

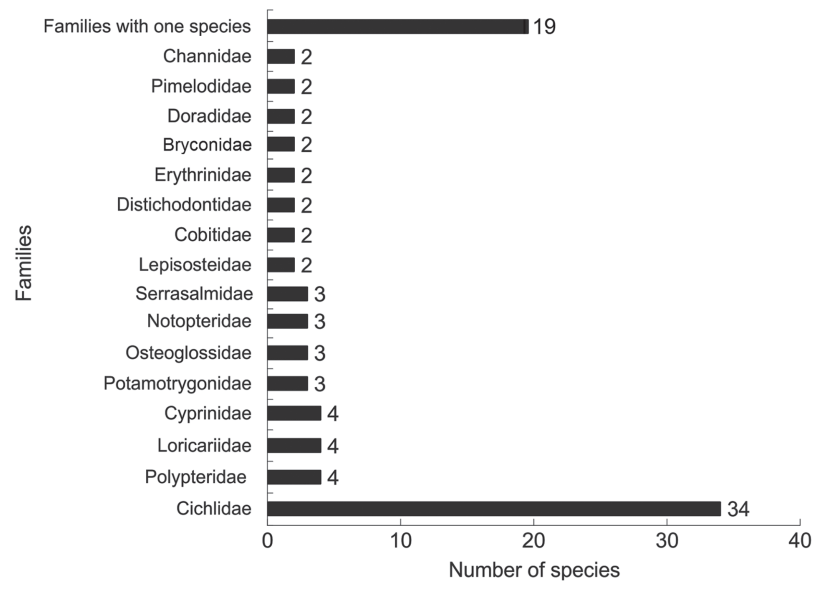

Fig. 2. Number of species of non-native large fish according to each family, recorded in the informal market held by Braziliam hobbyists, from May-2012 to September-2016. Families with only one species: Protopteridae, Arapaimidae, Mormyridae, Cynodontidae, Prochilodontidae, Ctenoluciidae, Pangasiidae, Bagridae, Mochokidae, Claroteidae, Clariidae, Auchenipteridae, Ictaluridae, Apteronotidae, Eleotridae, Osphronemidae, Centrarchidae, Sciaenidae, Datnioididae. 


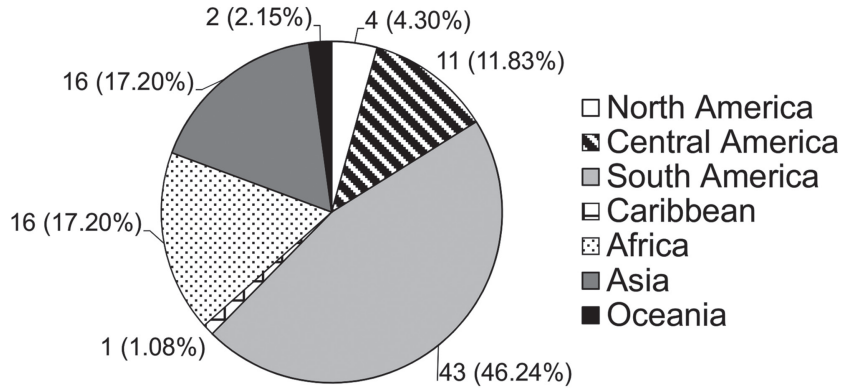

Fig. 3. Origin of non-native large fish species available among Brazilian hobbyists in the informal market.

Considering the 15 most traded species, juvenile length ranged from $3.0 \mathrm{~cm}$ (Heros severus Heckel, 1840) to 35.0 $\mathrm{cm}$ (Arapaima gigas (Valenciennes, 1847)), while their maximum adult length found in the literature ranged from $20.0 \mathrm{~cm}$ (H. severus and Herichthys carpintis (Jordan \& Snyder, 1899) + Amphilophus citrinellus (Günther, 1864) $\times$ Vieja melanura (Günther, 1862)) to $450.0 \mathrm{~cm}$ (A. gigas).
The mean length of juvenile fish on sale was significantly lower than their maximum lengths (Fig. 4a). JNLF are able to reach (on average) 7.5 times their sizes at retail, and they are usually sold with ca. $20 \%$ of their maximum lengths (Fig. $4 b)$. All species are sold at very small sizes $(<10.0 \mathrm{~cm}$ on average), and some show contrasting lengths if compared to their maximum adult length, such as Cichla temensis, Lepisosteus oculatus, Osteoglossum bicirrhosum (Cuvier, 1829), Pangasianodon hypophthalmus and A. gigas (Fig. 4c).

The number of specimens traded among the ten hobbyist groups averaged 10.5 individuals/species, considering the entire study period. The main species available were (Tab. 1): hybrid cichlid flowerhorn Amphilophus trimaculatus (Günther, 1867) × Amphilophus citrinellus, oscar Astronotus ocellatus (Agassiz, 1831), uaru Uaru amphiacanthoides Heckel, 1840, arowana $O$. bicirrhosum, blue peacock bass Cichla piquiti Kullander \& Ferreira, 2006, striped catfish P. hypophthalmus, finescale tigerfish Datnioides microlepis Bleeker, 1854 and yellow peacock bass C. kelberi Kullander \& Ferreira, 2006.
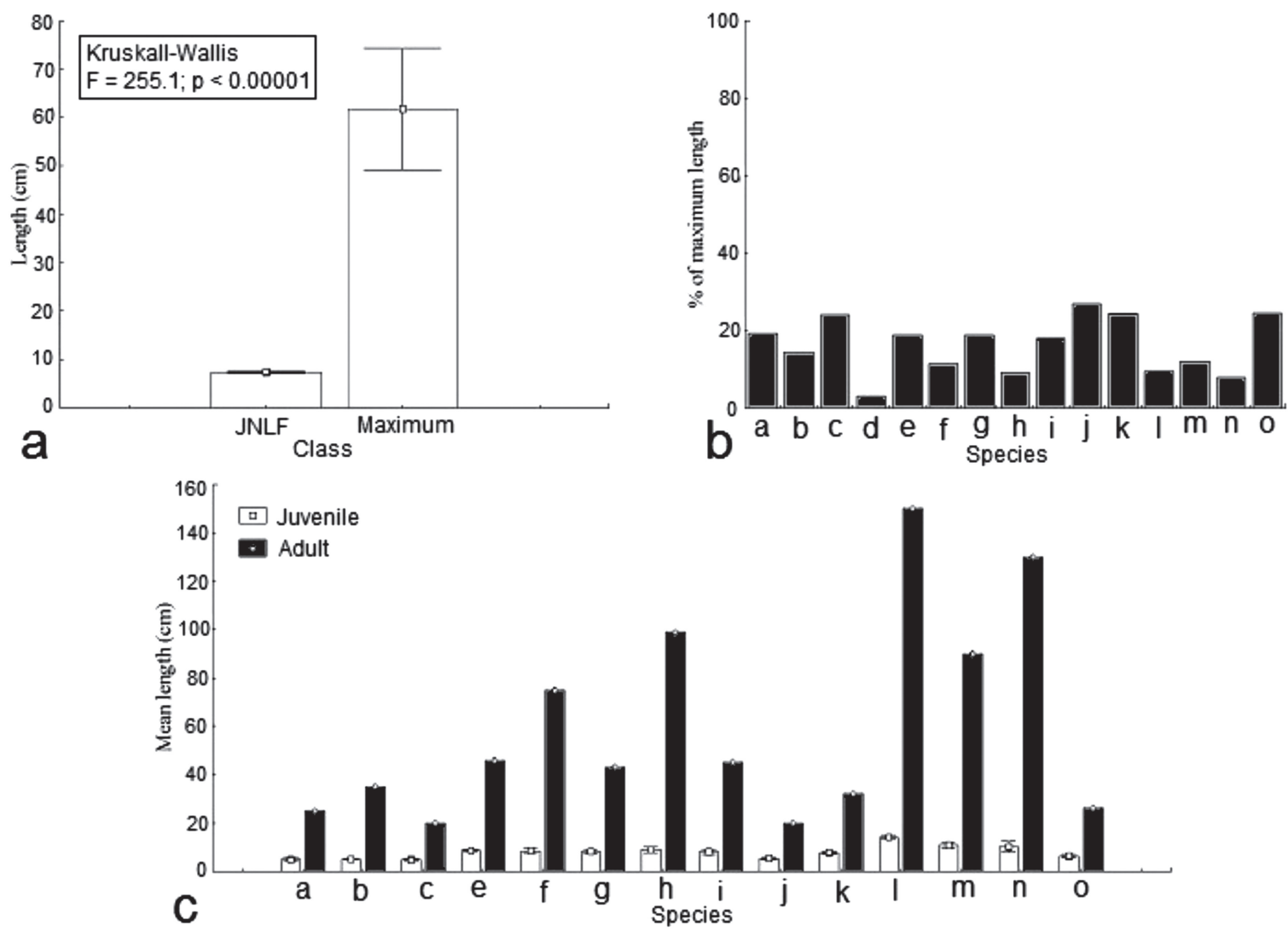

Fig. 4. Length data of non-native large fish, considering the top 15 species available among hobbyists in the unregulated market. a. Mean length of 768 juvenile specimens $( \pm 95 \% \mathrm{CI})$ and mean maximum lengths of available species (tested through non-parametric Kruskall-Wallis); b. Sizes of available fishes as percentage of their maximum lengths; c. Mean length of species available in the market and their respective maximum lengths. Species codes: a $=$ Amphilophus citrinellus $\times$ Vieja melanura; $\mathrm{b}=$ Amphilophus trimaculatus $\times$ Amphilophus citrinellus; $\mathrm{c}=$ Herichthys carpintis + Amphilophus citrinellus $\times$ Vieja melanura $; \mathrm{d}=$ Arapaima gigas $; \mathrm{e}=$ Astronotus ocellatus $; \mathrm{f}=$ Cichla kelberi; $\mathrm{g}=$ Cichla piquiti $; \mathrm{h}=$ Cichla temensis $; \mathrm{i}=$ Datnioides microlepis; $\mathrm{j}=$ Heros severus $; \mathrm{k}=$ Hoplarchus psittacus $; \mathrm{l}=$ Lepisosteus oculatus; $\mathrm{m}=$ Osteoglossum bicirrhosum; $\mathrm{n}=$ Pangasianodon hypophthalmus; o = Uaru amphiacanthoides. The species Arapaima gigas was ommited from figure c because of its large size (mean JNLF $=13.6 \mathrm{~cm}$; maximum $=450.0 \mathrm{~cm}$ ). 
Tab. 1. Top 15 non-native large fishes available in the unregulated market, monitored between May-2012 and September-2016. The table shows information about family, common/scientific name, native origin, juvenile and maximum adult length $(\mathrm{cm})$, aggressiveness, number of specimens available $(\mathrm{N})$ and their relative frequency $(\%)$. ${ }^{*}$ References - 1: Axelrod, 1992; 2 : Sandford, Crow, 1996; 3: Axelrod et al., 2005; 4: Nico et al., 2007; 5: Ng, Tan, 2010; 6: Herder et al., 2012; 7: Jaafar et al., 2012; 8: Liew et al., 2012; 9: Carvalho et al., 2014; 10: Pelicice et al., 2015; 11: Motionaquaticsuk, 2016; 12: Froese, Pauly, 2016.

\begin{tabular}{|c|c|c|c|c|c|c|c|c|}
\hline Family & Common name Scientific name & Origin & Juvenile (range) & Adult & Behavior & $\mathrm{N}$ & $\%$ & * Refs. \\
\hline Cichlidae & $\begin{array}{l}\text { flowerhorn } \\
\text { Amphilophus trimaculatus } \times \text { Amphilophus citrinellus }\end{array}$ & Asia & $4.0-9.0$ & 35.0 & Aggressive & 294 & 30.28 & $\begin{array}{l}4,5 \\
6,7\end{array}$ \\
\hline Cichlidae & $\begin{array}{l}\text { oscar } \\
\text { Astronotus ocellatus }\end{array}$ & South America & $5.0-13.0$ & 45.7 & Aggressive & 66 & 6.80 & $\begin{array}{c}1,2,3 \\
8,12\end{array}$ \\
\hline Cichlidae & $\begin{array}{l}\text { uaru } \\
\text { Uaru amphiacanthoides }\end{array}$ & South America & $5.0-9.0$ & 26.0 & Harmless & 50 & 5.15 & 3,12 \\
\hline Osteoglossidae & $\begin{array}{l}\text { arowana } \\
\text { Osteoglossum bicirrhosum }\end{array}$ & South America & $7.0-20.0$ & 90.0 & Aggressive & 45 & 4.63 & $1,2,3$ \\
\hline Cichlidae & $\begin{array}{l}\text { blue peacock bass } \\
\text { Cichla piquiti }\end{array}$ & South America & $5.0-16.0$ & 43.0 & Aggressive & 42 & 4.32 & 9,12 \\
\hline Pangasiidae & $\begin{array}{l}\text { striped catfish } \\
\text { Pangasianodon hypophthalmus }\end{array}$ & Asia & $4.0-40.0$ & 130.0 & Harmless & 40 & 4.12 & 3,12 \\
\hline Datnioididae & $\begin{array}{l}\text { finescale tigerfish } \\
\text { Datnioides microlepis }\end{array}$ & Asia & $5.0-14.0$ & 45.0 & Aggressive & 35 & 3.60 & 5,12 \\
\hline Cichlidae & $\begin{array}{l}\text { yellow peacock bass } \\
\text { Cichla kelberi }\end{array}$ & South America & $6.0-15.0$ & 75.0 & Aggressive & 32 & 3.29 & 9,10 \\
\hline Lepisosteidae & $\begin{array}{l}\text { spotted gar } \\
\text { Lepisosteus oculatus }\end{array}$ & North America & $10.0-27.0$ & 150.0 & Aggressive & 28 & 2.88 & 3,12 \\
\hline Cichlidae & $\begin{array}{l}\text { blood parrot } \\
\text { Amphilophus citrinellus } \times \text { Vieja melanura }\end{array}$ & Asia & $4.0-9.0$ & 25.0 & Aggressive & 28 & 2.88 & 8 \\
\hline Cichlidae & $\begin{array}{l}\text { lowland cichlid-blood parrot } \\
\text { Herichthys carpintis }+ \text { Amphilophus citrinellus } \times \\
\text { Vieja melanura }\end{array}$ & Asia & $4.0-8.0$ & 20.0 & Aggressive & 27 & 2.78 & 11 \\
\hline Cichlidae & $\begin{array}{l}\text { parrot cichlid } \\
\text { Hoplarchus psittacus }\end{array}$ & South America & $7.0-9.0$ & 32.0 & Aggressive & 23 & 2.37 & 3,12 \\
\hline Cichlidae & $\begin{array}{l}\text { speckled pavon } \\
\text { Cichla temensis }\end{array}$ & South America & $7.0-15.0$ & 99.0 & Aggressive & 22 & 2.27 & 8,12 \\
\hline Cichlidae & $\begin{array}{l}\text { banded cichlid } \\
\text { Heros severus }\end{array}$ & South America & $3.0-7.0$ & 20.0 & Aggressive & 22 & 2.26 & 5,12 \\
\hline Arapaimidae & $\begin{array}{l}\text { giant arapaima } \\
\text { Arapaima gigas }\end{array}$ & South America & $9.0-35.0$ & 450.0 & Aggressive & 14 & 1.44 & 3,12 \\
\hline
\end{tabular}

The risk assessment (FIST) for potential biological invasion via aquarium dumping indicated that three species were considered high-risk, seven are moderate-risk and five are low-risk (Tab. 2). One important aspect is that most of the top 15 species display aggressive behavior (86.67\%), a trait commonly associated with pet rejection among hobbyists and the consequent dumping into the new environments.

The southeast region $(93.59 \%)$, represented by the cities of São Paulo (SP: 77.62\%), Rio de Janeiro (RJ: $12.72 \%$ ) and Belo Horizonte (BH: 3.25\%), showed the greatest informal trade activity. The northeast region (5.62\%), represented by the cities of São Luiz (SL: 0.10\%), Fortaleza (FO: 0.29\%), João Pessoa (JP: 0.20\%), Recife (RE: 3.05\%) and Salvador (SA: 1.98\%), showed much lower activity (Fig. 5).

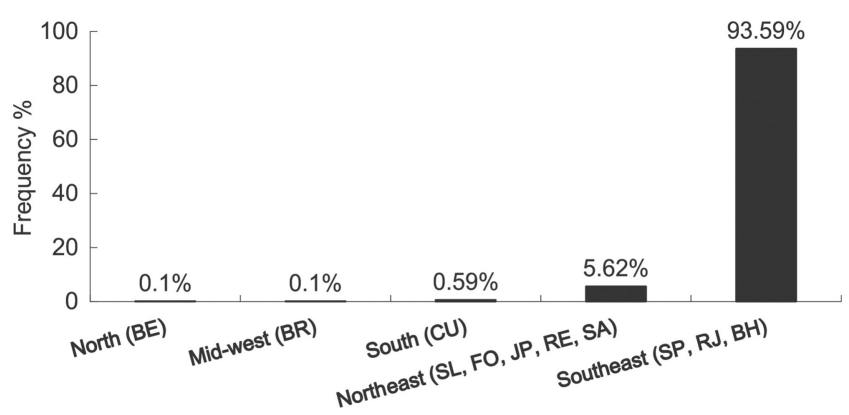

Fig. 5. Five Brazilian geopolitical regions and the 11 big cities (BE - Belém, BR - Brasília, CU - Curitiba, SL - São Luís, FO - Fortaleza, JP - João Pessoa, RE - Recife, SA Salvador, SP - São Paulo, RJ - Rio de Janeiro, BH - Belo Horizonte) where hobbyists traded juveniles of non-native large fish, between May-2012 and September-2016. 
Tab. 2. Results of the Fish Invasiveness Screening Test (FIST) calculated for the 15 most available non-native large fishes. 1: Maximum adult length $(\mathrm{cm}), 2$ : Aggressiveness, 3: Tolerance to salinity, 4: History of establishment, 5: Ability to breed in the wild, 6: Competition with native species, + : low; ++: moderate, +++ : high. FD $\%=$ frequency of +++ among traits.

\begin{tabular}{|c|c|c|c|c|c|c|c|}
\hline \multirow{2}{*}{ Species invasiveness assessment } & \multicolumn{6}{|c|}{ Invasiveness screening criteria } & \multirow{2}{*}{ Risk (FD \%) } \\
\hline & 1 & 2 & 3 & 4 & 5 & 6 & \\
\hline Arapaima gigas & +++ & +++ & + & + & +++ & +++ & High (66.67) \\
\hline Cichla kelberi & +++ & +++ & + & ++ & +++ & +++ & High (66.67) \\
\hline Cichla temensis & +++ & +++ & + & + & +++ & +++ & High (66.67) \\
\hline Astronotus ocellatus & ++ & +++ & + & ++ & +++ & +++ & Medium (50.00) \\
\hline Cichla piquiti & ++ & +++ & + & ++ & +++ & +++ & Medium (50.00) \\
\hline Amphilophus trimaculatus $\times$ Amphilophus citrinellus & + & +++ & ++ & + & +++ & +++ & Medium (50.00) \\
\hline Heros severus & + & +++ & ++ & + & +++ & ++ & Medium (33.33) \\
\hline Hoplarchus psittacus & + & +++ & + & + & +++ & ++ & Medium (33.33) \\
\hline Lepisosteus oculatus & +++ & +++ & + & + & ++ & ++ & Medium (33.33) \\
\hline Osteoglossum bicirrhosum & +++ & +++ & + & + & ++ & ++ & Medium (33.33) \\
\hline Datnioides microlepis & ++ & +++ & + & + & + & + & Low (16.67) \\
\hline Uaru amphiacanthoides & + & + & + & + & +++ & ++ & Low (16.67) \\
\hline Pangasianodon hypophthalmus & +++ & + & + & ++ & + & + & Low (16.67) \\
\hline Amphilophus citrinellus $\times$ Vieja melanura & + & + & + & + & + & + & Low $(0)$ \\
\hline Herichthys carpintis + Amphilophus citrinellus $\times$ Vieja melanura & + & ++ & + & + & + & + & Low (0) \\
\hline
\end{tabular}

\section{Discussion}

We found a large number of species ( $\mathrm{n}=93$ ), most native to South America and traded among Brazilian hobbyists over the study period (almost five years), indicating that many ornamental non-native large fishes are available in the unregulated market. Our study is just a sample of the nonregulated market, so the number of new species and flow of fish among hobbyists must be much higher. For example, sales of largemouth bass Micropterus salmoides (Lacepède, 1802), Mexican mojarra Mayaheros urophthalmus (Günther, 1862) and Ginean bichir Polypterus ansorgii Boulenger, 1910, juveniles emerged in one of the monitored groups during March and April 2017 (A.L.B. Magalhães, pers. obs.), although these non-native species were not detected in our survey. In addition, we monitored only ten aquarium groups, but a quick search on Facebook ${ }^{\circledR}$ showed the existence of at least 20 groups selling JNLF. Large-bodied species were formerly sold only in aquarium stores, but the popularity of social media and e-commerce increased the potential market. At present, JNLF can be easily purchased by consumers located outside large urban centers, a nonmonitored system that may enhance aquarium dumping and fish invasions across the country.

In our survey, Cichlidae was the main family in the informal market. Cichlids are among the most popular aquarium fishes due to aesthetic aspects such as diversity of colors (Mann, Sefc, 2013) and easiness of rearing in aquaria (Liang et al., 2006). Many hobbyists maintain their own breeding stocks, which also explains the desirability for this family (Liew et al., 2012). Several cichlids, however, are highly territorial, predatory and grow to large sizes, i.e, traits that make theses fishes good candidates to become undesirable and dumped. In the wild, large cichlids exhibit extended breeding seasons and aggressive parental care (Bomford, Glover, 2004), enhancing survival of the young and granting them competitive advantage over native species (van Breukelen, 2015). In addition, some nonnative species found here such as hybrid flowerhorn, oscar, banded cichlid and the lowland cichlid Herichthys carpintis are euryhaline, able to survive in mesohaline conditions for extended periods of time (Jaafar et al., 2012; Liew et al., 2012; Gutierre et al., 2016; Froese, Pauly, 2016), with the possibility to use brackish waters of mangroves/estuaries as dispersal routes (i.e, dispersion bridges) (Gutierre et al., 2014). Of the 11 cities evaluated, seven $(63.64 \%)$ have mangroves and estuaries in their urban perimeters; if these euryhaline species invade these environments, the chance of establishment is high.

All species recorded were traded as juveniles at very small lengths, but all can attain large sizes at maturity; in addition, the majority display aggressive behavior. The same trend was found by Holmberg et al. (2015) for more than 700 large marine aquarium fish species, such as the giant grouper Epinephelus lanceolatus (Bloch, 1790) and the lionfish Pterois volitans (Linnaeus, 1758), sold in the U.S.A. aquarium trade. The small size at the retailing stage is a key factor behind the introduction of large-sized fishes, because many hobbyists are ignorant about species biology and behavior. Species biology may influence the likelihood of deliberate releases in two ways: first and most important, fish become too large and aggressive (Duggan et al., 2006; Gertzen et al., 2008); and second, proliphic species (e.g. some cichlids) may quickly overpopulate the aquaria, especially because fecundity is size-dependent (Liew et al., 2012). Both aspects are the main reasons for deliberate aquarium fish releases (Bomford, Glover, 2004; Magalhães, Jacobi, 2013a). 
Top eight JNLF commonly sold in Brazil have already invaded different regions of the planet, some with negative effects on biodiversity. For example, the hybrid flowerhorn is established in Sulawesi and threatens the endemic goby Glossogobius matanensis (Weber, 1913) through predation and competition (Herder et al., 2012). Astronotus ocellatus competes with native species in canals of the Everglades National Park, U.S.A (Trexler et al., 2000). Pangasianodon hypophthalmus introduced in Poland either hosts or transmitted a monogenoid parasite, Thaparocleidus caecus (Mizelle \& Kritsky, 1969), posing threat to native fishes (Wiecaszek et al., 2009). A concerning trend is the increasing demand for peacock basses (Cichla) as pet fish. These fishes are the major group of piscivorous cichlids in South America, successful invaders of environments disturbed by human activities (Espínola et al., 2010). In Brazil, two large cichlids, C. piquiti and C. kelberi, are extensively established in non-Amazonian basins (Carvalho et al., 2014), and studies have shown that the introduction of these fishes is associated with deleterious effects on local fish assemblages (Carvalho et al., 2014; Pelicice et al., 2015). Although the invasion of Cichla is usually associated to sport fisheries, the importance of aquarium dumping may increase in next years, since these species are now popular among hobbyists in Brazil and elsewhere. We highlight that the Fish Invasiveness Screening Test has identified A. gigas, C. kelberi and C. temensis as high-risk species. As preventive measure, we recommend stringent control on the trade of giant arapaima and peacock basses. Top-predators have great potential to negatively affect the abundance of native biota and cause the extirpations of benthic invertebrates and fish (Gallardo et al., 2016).

The southeast region showed the greatest availability of JNLF especially in São Paulo and Rio de Janeiro. These cities, located in areas of Atlantic Rainforest, one of the world's biodiversity hotspots, are the most populous in the country. They are also the main center of aquarium trade, with more than 1,000 aquarium stores (Pinheiro et al., 2008) and thousands of fishkeepers (Magalhães, Jacobi, 2010). This geopolitical region has also the highest number of non-native large fishes introduced due to aquarium dumping, such as the goldfish $C$. auratus (Linnaeus, 1758), koi carp Cyprinus carpio Linnaeus, 1758, pike cichlid Crenicichla macrophthalma Heckel, 1840, eartheater cichlids Geophagus proximus (Castelnau, 1855), G. surinamensis (Bloch, 1791), pond loach Misgurnus anguillicaudatus (Cantor, 1842), A. ocellatus and jaguar guapote Parachromis managuensis (Günther, 1867) (Gomes et al., 2011; Vitule et al., 2014a; Latini et al., 2016). According to Magalhães (2015), identifying high-risk areas is necessary to devise management measures in geographic regions where invasions are more likely. The release of non-native large fishes into urban waters of Brazil has a recent history, but the scenario indicates that invasibility is high. Many ecosystems are disturbed by multiple human activities such as reservoirs, public ponds and urbanized mangroves/estuaries (Magalhães, Jacobi, 2013a; França et al., 2017; Pelicice et al., 2017). In adition, several regions in Brazil have a constant warm climate (Magalhães, Jacobi, 2013a; Latini et al., 2016; França et al., 2017), a scenario that may enhance the establishment of tropical non-native fishes. Therefore, the growing popularity of these fishes (Gomes et al., 2011; Magalhães, Jacobi, 2013a; Assis et al., 2014; Garcia et al., 2014; Magalhães, 2015; França et al., 2017), coupled with densely populated cities (IBGE, 2016), indicate that fish invasions and subsequent establishment will increase in next years. We highlight, however, that the successful invasion of some ornamental non-native large fishes does not necessarily demand a high propagule pressure. For instance, the establishment of $C$. auratus in Teller Lake \#5, Colorado State (U.S.A), is believed to have stemmed from the release of a small number of founder fish, probably as unwanted pets. This species, with a current population of 3,000 to 4,000 individuals, is now a significant pest threatening local wildlife (Bryner, 2015).

Our findings suggest the need to improve management strategies to prevent further introductions of JNLF via aquarium dumping. Firstly, given that home aquariums are the major potential source of future invaders, a more rigorous system controlling fish keeping should be priority. Thus, we recommend authorities to advise and encourage hobbyists toward better practices concerning the correct disposal of nuisance fish. Aquarium stores and traders could teach hobbyists to return undesirable fishes to retailers (i.e, "reverse logistics") or donate to public institutions (e.g. schools, zoos). A more stringent and effective measures is euthanizing undesirable fishes (Gomes et al., 2011), although hobbyists usually show resistance. Secondly, environmental agencies should work together with Facebook $^{\circledR}$ Serviços Online do Brasil Ltda. to post alert messages in the pictures of JNLF for sale in aquarium groups, indicating simple ecological traits and other information (e.g. adult sizes, feeding behavior, tolerance to salinity, aggressiveness, prolificacy, disease vector). Recently, Magalhães, Jacobi (2010) suggested Brazilian virtual petshops and other social media to inform hobbyists about species traits as a means of reducing rejection and subsequent aquarium dumping. Thirdly, environmental agencies (e.g. Brazilian Institute of Environment and Renewable Natural Resources-IBAMA) must look for new communication tools, like the newly WhatsApp Messenger (www.whatsapp.com) or develop other smartphone apps, which provides an effective mean to reach hobbyists. For example, environmental agencies of U.S.A, Europe and the Fundación Humedales (Colombia) has developed free apps named respectively IveGot1, That's Invasive! and InvBasa, to provide awareness about new invasions (Adriaens et al., 2015; Wallace et al., 2016, Fundacion Humedales, 2017). Lastly, and more importantly, it is necessary to implement educational programs to provide high-quality information to hobbyists, retailers and fish farmers (Azevedo-Santos et al., 2015), as for example, informing about threats 
related to the introduction of non-native fish, and the list of invasive species forbidden in the market (e.g. Federal Law 203 of 2008 which prohibits the importation of $P$. hypophthalmus). These programs could be offered by environmental agencies (e.g. IBAMA), universities and association of retailers (e.g. Brazilian Association of Aquarium Stores-ABLA) (Magalhães, 2015).

By surveying the sales of JNLF through informal markets, we offered an opportunity to understand this new high-risk pathway - especially because this fish trade has public empathy and flourishes in Brazil (Gomes et al., 2011; Magalhães, Jacobi, 2013a; Assis et al., 2014; Garcia et al., 2014; Magalhães, 2015; França et al., 2017). Moreover, the new Brazilian Normative Instruction 16 of 2014 (previous Ministry of Fishing and Aquaculture), which allows the trade of hundreds of large ornamental fish species (Vitule et al., 2014b), together with Normative Instruction 21 of 2014, which will facilitate the transport of these fishes across the country (Lima-Junior et al., 2015), will favor aquarium dumping and further increase biological invasions, with negative effects on native biodiversity - for example, biotic homogenization (i.e, the temporal replacement of endemic and specialists native species by generalist and human commensal non-native species) (Vitule et al., 2012) or additive heterogenization (i.e, non-native species establish, but few become ubiquitous) (Socolar et al., 2016). According to Frehse et al. (2016), authorities do not recognize the Brazilian aquarium trade as a major introduction pathway; however, in terms of propagule pressure and species diversity, such trade is a major and unpredictable source of introductions. It deserves better investigation, monitoring and control by Brazilian policies and environmental agencies.

\section{Acknowledgments}

The authors are grateful to CAPES (Coordenação de Aperfeiçoamento de Pessoal de Nível Superior) and CNPq (Conselho Nacional de Desenvolvimento Científico e Tecnológico) for scholarships and constant financial support. We also thank two anonymous reviewers for their valuable comments.

\section{References}

Adriaens T, Sutton-Croft M, Owen K, Brosens D, van Valkenburg J, Kilbey D, Groom Q, Ehmig C, Thürkow F, Van Hende P, Schneider $\mathrm{K}$. Trying to engage the crowd in recording invasive alien species in Europe: experiences from two smartphone applications in northwest Europe. Manag Biol Invasion 2015; 6(2):215-25.

American Pet Products Manufacturer Association (APPMA). National Pet Owners Survey. American Pet Products Manufacturer Association; 2008.

AquaA3. Peixes ornamentais são o segundo pet preferido pelos brasileiros; 2015 [cited 2015 Aug 16]. Available from: https:// www.aquaa3.com.br/2015/04/peixes-ornamentais-sao-osegundo-pet-preferidos-pelos-brasileiros.html
Assis DAS, Cavalcante SS, Brito MFG. Aquarium trade as a potential disseminator of non-native invertebrates in Northeastern Brazil. Neotrop Biol Conserv. 2014; 9(2):115-19

Axelrod HR. Jumbo Fishes for the Large Aquarium. Neptune City: TFH Publications; 1992.

Axelrod GS, Scott BM, Pronek N. Encyclopedia of Exotic Tropical Fishes for Freshwater Aquariums. Neptune City: TFH Publications; 2005.

Azevedo-Santos VM, Pelicice FM, Lima-Junior DP, Magalhães ALB, Orsi ML, Vitule JRS, Agostinho AA. How to avoid fish introductions in Brazil: education and information as alternatives. Nat Conservação. 2015; 13(2):123-32.

Bomford M, Glover J. Risk assessment model for the import and keeping of exotic freshwater and estuarine finfish. Canberra: Bureau of Rural Sciences Technical report; 2004.

van Breukelen NA. Interactions between native and non-native cichlid species in a Costa Rican river. Environ Biol Fishes. 2015; 98(3):885-89.

Bryner J. 3,000 Goldfish! Dumped Aquarium Pets Multiply in Lake; 2015 [cited 2015 Apr 09]. Available from: http://www. livescience.com/50442-3000-goldfish-multiply-in-lake.html

Carvalho DC, Oliveira DAA, Sampaio I, Beheregaray LB. Analysis of propagule pressure and genetic diversity in the invasibility of a freshwater apex predator: the peacock bass (genus Cichla). Neotrop Ichthyol. 2014; 12(1):105-16.

Convention on Biological Diversity (CBD). Pets, Aquarium, and terrarium species: best practices for addressing risks to biodiversity. Montreal: Secretariat of the Convention on Biological Diversity; 2010.

Chapman, FA Ornamental fish culture - Freshwater. In: Stickney RR, editor. Encyclopedia of aquaculture. New York: John Wiley \& Sons; 2000. p.602-610.

Duggan I, Rixon CAM, MacIsaac HJ. Popularity and propagule pressure: determinants of introduction and establishement of aquarium fish. Biol Invasions. 2006; 8(2):377-82.

Edwards NE, Beck AM. Animal-assisted therapy and nutrition in Alzheimer's disease. West J Nurs Res. 2002; 24(6):697-712.

Eschmeyer WN, Fricke R, van der Laan R, editors. Catalog of fishes: genera, species, references. [Electronic Version]. San Francisco (CA): California Academy of Sciences; 2017. [cited 2017 Jul 19]. Available from: http:// researcharchive.calacademy.org/research/ichthyology/ catalog/fishcatmain.asp

Espínola LA, Minte-Vera CV, Júlio Jr. HF. Invasibility of reservoirs in the Paraná Basin, Brazil, to Cichla kelberi Kullander and Ferreira, 2006. Biol Invasions 2010; 12(6):1873-88.

França EJ, Almeida CAC, Almeida Neto MS, Santos RE, Magalhães ALB, El-Deir ACA, Severi W. Novelty on the market, novelty in the environment: the invasion of nonnative fish jaguar guapote (Perciformes) in northeastern Brazil. Neotrop Biol Conserv. 2017; 12(1):12-18.

Frehse FA, Braga RR, Nocera GA, Vitule JRS. 2016. Non-native species and invasion biology in a megadiverse country: scientometric analysis and ecological interactions in Brazil. Biol Invasions. 2016; 18(12):3713-25. 
Froese R, Pauly D, editors. FishBase. [World Wide Web electronic publication]. Penang (MA), Rome: FAO; 2016 [cited 2016 Sep 06]. Available from: http://fishbase.org

Fundacion Humedales. Aplicación InvBasa para el registro de especies invasoras; 2017 [cited 2017 Jul 04]. Available from: http://fundacionhumedales.org/wp/portfolio/invbasa/

Gallardo B, Clavero M, Sánchez MI, Vilà M. Global ecological impacts of invasive species in aquatic ecosystems. Glob Change Biol. 2016; 22(1):151-63.

Garcia DAZ, Almeida FS, Souza ATS, Britton JR, Orsi ML. Invasion characteristics of Pterygoplichthys ambrosettii (Holmberg, 1893) in the lower Paranapanema River, Brazil. J Appl Ichthyol. 2014; 30(5):1041-44.

Gertzen E, Familiar O, Leung B. Quantifying invasion pathways: fish introductions from the aquarium trade. Can J Fish Aquat Sci. 2008; 65(7):1265-73.

Gomes CIDA, Peressin A, Cetra M, Barrella W. First adult record of Misgurnus anguillicaudatus, Cantor 1842 from Ribeira de Iguape River Basin, Brazil. Acta Limnol Bras. 2011; 23(3):229-32.

Gutierre SMM, Schofield PJ, Prodocimo V. Salinity and temperature tolerance of an emergent alien species, the Amazon fish Astronotus ocellatus. Hydrobiologia 2016; 777(1):21-31.

Gutierre SMM, Vitule JRS, Freire CA, Prodocimo V. Physiological tools to predict invasiveness and spread via estuarine bridges: tolerance of Brazilian native and worldwide introduced freshwater fishes to increased salinity. Mar Freshwater Res. 2014; 65(5):425-36.

Herder F, Schliewen UK, Geiger MF, Hadiaty RK, Gray SM, McKinnon JS, Walter RP, Pfaender J. Alien invasion in Wallace's Dreamponds: records of the hybridogenic "flowerhorn" cichlid in Lake Matano, with an annotated checklist of fish species introduced to the Malili Lakes system in Sulawesi. Aquat Invasions. 2012; 7(4):521-35.

Holmberg RJ, Tlusty MF, Futoma E, Kaufman L, Morris JA, Rhyne AL. The 800-pound grouper in the room: asymptotic body size and invasiveness of marine aquarium fishes. Mar Policy 2015; 53:7-12.

Instituto Brasileiro de Geografia e Estatística (IBGE). Cidades; 2016. [cited 2016 Aug 20]. Available from: http://cidades.ibge. gov.br/xtras/perfil.php?lang=\& codmun=310620

Ishikawa $\mathrm{T}$, Tachihara $\mathrm{K}$. Introduction history of non-native freshwater fish in Okinawa-jima Island: ornamental aquarium fish pose the greatest risk for future invasions. Ichthyol Res. 2014; 61(1):17-26.

Jaafar Z, Yeo DCJ, Tan HH, O'Riordan RM. Status of estuarine and marine non-indigenous species in Singapore. Raffles Bull Zool. 2012; 25:79-92.

Latini AO, Oporto LT, Lima-Junior DP, Resende DC, Latini RO. Peixes. In: Latini AO, Resende DC, Pombo VB, Coradin L, editors. Espécies exóticas invasoras de águas continentais no Brasil. Brasília: Ministério do Meio Ambiente; 2016. p.295-649.

Liang SH, Chuang LC, Chang MS. The pet fish trade as a source of invasive fish in Taiwan. Taiwania. 2006; 51(2):93-98.

Liew JH, Tan HH, Yeo DCJ. Some cichlid fishes recorded in Singapore. Nat Singapore. 2012; 5:229-36.
Lima-Junior DP, Magalhães ALB, Vitule JRS. Dams, politics and drought threat: the march of folly in Brazilian freshwaters ecosystems. Nat Conservação 2015; 13(2):196-98.

Maceda-Veiga A, Domínguez-Domínguez O, Escribano-Alacid J, Lyons J. The aquarium hobby: can sinners become saints in freshwater fish conservation? Fish Fish. 2016; 17(3):860-74.

Magalhães ALB. Presence of prohibited fishes in the Brazilian aquarium trade: effectiveness of laws, management options and future prospects. J Appl Ichthyol. 2015; 31(1):170-72.

Magalhães ALB, Jacobi CM. Invasion risks posed by ornamental freshwater fish trade to southeastern Brazilian rivers. Neotrop Ichthyol. 2013a; 11(2):433-41.

Magalhães ALB, Jacobi CM. E-commerce of freshwater aquarium fishes: potential disseminator of exotic species in Brazil. Acta Sci Biol Sci. 2010; 32(3):243-48.

Mann ME, Sefc KM. Colour variation in cichlid fish: Developmental mechanisms, selective pressures and evolutionary consequences. Semin Cell Dev Biol. 2013; 24(6-7):516-28.

Marine and Coastal Committee. A strategic approach to the management of ornamental fish in Australia - Consultation draft. Canberra: Natural Resource Management Standing Committee Department of Agriculture, Fisheries and Forestry; 2005.

Motionaquaticsuk. Red Texas cichlid; 2016. [cited 2016 Sep 25]. Available from: http://www.motionaquatics.uk/red-texascichlid.html

Nelson JS, Grande TC, Wilson MVH. Fishes of the world. 5th ed. New Jersey: John Wiley \& Sons; 2016.

$\mathrm{Ng} \mathrm{HH}$, Tan HH. An annotated checklist of the non-native freshwater fish species in the reservoirs of Singapore. Cosmos. 2010; 6(1):95-116.

Nico LG, Beamish WH, Musikasinthorn P. Discovery of the invasive Mayan Cichlid fish "Cichlasoma" urophthalmus (Günther, 1862) in Thailand, with comments on other introductions and potential impacts. Aquat Invasions. 2007; 2(3):197-214.

Pelicice FM, Azevedo-Santos VM, Vitule JRS, Orsi ML, Lima Junior DP, Magalhães ALB, Pompeu PS, Petrere Jr M, Agostinho AA. Neotropical freshwater fishes imperilled by unsustainable policies. Fish Fish. 2017; 18(6):1119-33.

Pelicice FM, Latini JD, Agostinho AA. Fish fauna disassembly after introduction of a voracious predator: main drivers and the role of the invader's demography. Hydrobiologia. 2015; 746(1): 271-83.

Pinheiro C, Anatole H, Bosch TM. Diagnóstico geral das práticas de controle ligadas a exploração, captura, comercialização, exportação e uso de peixes para fins ornamentais e de aquariofilia. Brasília: Diretoria de Uso Sustentável da Biodiversidade e Florestas-IBAMA; 2008.

Reaser JK, Meyers NM. Habitattitude ${ }^{\mathrm{TM}}$ : getting a backbone about the pet release pathway. Fort Collins: Managing vertebrate invasive species: proceedings of an international symposium; 2007.

Sandford G, Crow R. The interpet manual of tank busters: an introduction to keeping and displaying large and impressive fish in the aquarium. Ladysmith: Salamander Books; 1996. 
Singh AK, Lakra WS. Risk and benefit assessment of alien fish species of the aquaculture and aquarium trade into India. Rev Aquacult. 2011; 3(1):3-18.

Socolar JB, Gilroy JJ, Kunin WE, Edwards DP. How should betadiversity inform biodiversity conservation? Trends Ecol Evol 2016; 31(1):67-80

Sokal RR, Rohlf FJ. Biometry: the principles and practice of statistics in biological research. 3rd ed. New York: W.H. Freeman; 1995.

Trexler JC, Loftus WF, Jordan F, Lorenz JJ, Chick JH, Kobza RM. Empirical assessment of fish introductions in a subtropical wetland: an evaluation of contrasting views. Biol Invasions. 2000; 2(4):265-77.

Vitule JRS, Skóra F, Abilhoa V. Homogenization of freshwater fish faunas after the elimination of a natural barrier by a dam in Neotropics. Divers Distrib. 2012; 18(2):111-20.
Vitule JRS, Magalhães ALB, Sampaio FDF. Legislação ambiental e peixes ornamentais no Brasil: onde estamos, para onde vamos e qual o papel dos ictiólogos. Bol Soc Bras Ictiol. 2014a; 111:2-7.

Vitule JRS, Sampaio FDF, Magalhães ALB. Monitor Brazil's fish sampling closely. Nature. 2014b; 513:315.

Wallace RD, Bargeron CT, Moorhead DJ, LaForest JH. IveGot1: reporting and tracking invasive species in Florida. Southeast Nat. 2016; 15(8):51-62.

Wiecaszek B, Kaeszka S, Sobecka E, Boeger W. Asian pangasiids - an emerging problem for European inland waters? Systematic and parasitological aspects. Acta Ichthyol Piscat. 2009; 39(2):131-38.

Submitted March 05, 2017

Accepted October 19, 2017 by Katya Kovalenko 